\title{
Upaya Guru Memotivasi Belajar Siswa Dalam Pembelajaran IPS Di SMP Negeri 2 Palangka Raya
}

\author{
Y. Yana, S. Rohaetin, R. Oktobery \\ Program Studi Pendidikan Ekonomi \\ Fakultas Keguruan dan Ilmu Pendidikan \\ Universitas Palangka Raya \\ Kampus UPR Tunjung Nyaho Jalan Hendrik, Indonesia \\ (Diterima 22-10-2019; Disetujui 26-11-2019)
}

\begin{abstract}
ABSTRAK
Motivasi belajar adalah keseluruhan daya penggerak didalam diri siswa yang menimbulkan kegiatan belajar menjamin kelangsungan dan memberikan arah pada kegiatan belajar sehingga tujuan yang dikehendaki dapat tercapai. Dalam motivasi belajar dorongan merupakan kekuatan mental untuk melakukan kegiatan dalam rangka pemenuhan harapan dan dorongan dalam hal ini adalah pencapaian tujuan. Ada dua jenis motivasi yaitu motivasi intrinsik dan motivasi ekstrinsik. Guru sebagai pendidik dan pengajar tentu mengupayakan agar siswa dan siswi dapat belajar dengan baik, sehingga prestasi belajar meningkat sehinggadapat menyamai prestasi belajar temantemannya atau bahkan diatas rata-rata kelas. Tujuan penelitian ini adalah untuk mengetahui apa saja upaya guru untuk memotivasi belajar siswa dalam pembelajaran IPS di SMP Negeri 2 Palangka Raya.

Penelitian ini dilakukan dengan menggunakan metode deskriptif dengan melibatkan 45 orang siswa SMP Negeri 2 Palangka Raya, Data dijaring melalui angket secara tertutup (angket tertutup) untuk siswa yang diperkuat dengan hasil wawancara kepada Guru IPS dan dianalisis dengan menggunakan rumus persentase. Dari hasil wawancara diketahui bahwa dari 90 populasi siswa kelas VIII-8, VIII-9 dan VIII-10 masih ada siswa yang memperoleh nilai dibawah KKM (Kriteria Ketuntasan Minimal) yaitu 75, hal ini dikarenakan banyaknya siswa kurang aktif dalam mengikuti KBM (Kegiatan Belajar Mengajar) yang berlangsung. ada siswa yang menggunakan waktunya untuk hal-hal yang kurang bermanfaat dengan bermain dengan kawan-kawannya saat proses pembelajaran berlangsung, Dari hasil angket upaya guru untuk memotivasi belajar siswa dalam pembelajaran IPS di SMP Negeri 2 Palangka Raya dinyatakan bahwa guru telah melakukan upaya dalam memotivasi belajar siswa. Usaha-usaha yang telah dilakukan oleh guru antara lain : memberikan angka/nilai, memberi hadiah, memberi ulangan, memberi pujian, memberi hukuman dan memberi metode pembelajaran yang bervariasi.
\end{abstract}

Kata Kunci: Upaya Guru, motivasi

\section{PENDAHULUAN}

Pendidikan adalah usaha sadar untuk menumbuh kembangkan potensi sumber daya manusia melalui kegiatan pengajaran. Salah satu faktor dari dalam diri yang menentukan berhasil tidaknya dalam proses belajar-mengajar adalah motivasi belajar. Dalam belajar masing-masing siswa memiliki motivasi belajar yang berbeda-beda. Ada siswa yang memiliki motivasi belajar tinggi dan ada pula siswa yang memiliki motivasi belajar rendah. Pendidikan termasuk salah satu yang sangat penting dalam menentukan kelangsungan kehidupan masyarakat atau suatu bangsa kearah yang 
lebih maju, oleh karenanya pendidikan harus mendapat perhatian yang sungguh-sungguh dari semua pihak baik dari pemerintah maupun dari masyarakat.

Maju mundurnya suatu masyarakat atau suatu bangsa banyak tergantung kepada sejauh mana kualitas pendidikan yang dimiliki oleh masyarakat atau suatu bangsa itu sendiri. Segala sesuatu dalam pendidikan mestinya diupayakan untuk mencapai tujuan pendidikan nasional sebagaimana yang tertuang dalam UU No. 20 tahun 2003 tentang sistem pendidikan nasional, Pendidikan nasional bertujuan untuk meningkatkan berkembangnya potensi peserta didik agar menjadi manusia yang beriman dan bertaqwa kepada Tuhan Yang Maha Esa, berbudi pekerti luhur, berahlak mulia, sehat berilmu, cakap, kreatif, mandiri dan menjadi warga Negara yang demokratis serta bertanggung jawab.

Tujuan dari pendidikan mengandung atau mencerminkan keinginan dan sekaligus harapan masyarakat Indonesia terhadap penyelenggaraan pendidikan yang berkualitas baik pendidikan formal dan pendidikan nonformal. Dengan demikian pendidikan merupakan suatu proses dalam rangka mempengaruhi siswa agar dapat menyesuaikan diri sebaik mungkin terhadap lingkungannya yang akan menimbulkan perubahan dirinya, tercapainya tujuan pendidikan merupakan harapan semua pihak lembaga pendidikan itu sendiri, masyarakat dan guru, dalam hal ini guru sebagai individu utama yang banyak terlibat dalam pencapaian tujuan pendidikan karena guru secara langsung bertanggung jawab memberikan bimbingan dan pembinaan terhadap siswa dalam proses belajar mengajar.

Dalam rangka mewujudkan cita-cita nasional yang ingin dicapai melalui pendidikan, pemerintah menyelenggarakan suatu sistem pendidikan dan pengajaran secara nasional, sekaligus memberikan kesempatan warga Negara untuk melaksanakan pendidikan dan pengajaran. Oleh sebab itu sekolah terutama SMP mempunyai tujuan untuk menciptakan atau menyiapkan peserta didik agar mempunyai kemampuan untuk melanjutkan ke jenjang pendidikan yang lebih tinggi yaitu SMA dan perguruan tinggi. Salah satu usaha yang digunakan untuk mewujudkan tujuan tersebut adalah meningkatkan prestasi belajar siswa.

Dalam usaha meningkatkan kualitas peserta didik, maka tenaga kependidikan pun juga perlu ditingkatkan melalui berbagai kegiatan seperti pelatihan-pelatihan, kursus, penataan, maupun peningkatan kualifikasi guru melalui program penyetaraan dan lain-lain, sehingga dari tahun ke tahun kualitas guru tetap ditingkatkan. Motivasi belajar sering dikenali sebagai daya dorong untuk mencapai hasil yang baik yang biasanya diwujudkan dalam bentuk tingkah laku belajar atau menunjukkan usaha-usaha untuk mencapai tujuan belajar. Betapa pentingnya sebuah motivasi bagi setiap orang dalam kehidupan sehari-hari khususnya dalam kegiatan proses belajar-mengajar.

Guru sebagai pendidik tidak hanya menyampaikan materi atau pelajaran di dalam kelas saja, akan tetapi harus bisa memberikan motivasi kepada siswa. Untuk menumbuhkan motivasi belajar siswa yang tinggi, maka upaya guru dan siswa sangatlah dibutuhkan, sebab hanya seorang gurulah dan siswa itu sendiri yang mampu menumbuhkan motivasi belajar siswa pada saat berada di dalam kelas.

Sebagai pengajar, guru seharusnya membantu perkembangan siswa untuk dapat menerima dan memahami serta menguasai ilmu pengetahuan dan teknologi. Untuk itu guru harus memotivasi siswa agar senantiasa belajar dalam berbagai kesempatan. Pada akhirnya, seorang guru dapat memainkan perannya sebagai motivator dalam proses belajar mengajar bila guru itu menguasai dan mampu melakukan keterampilan-keterampilan yang relevan dengan situasi dan kondisi para siswa. Dengan demikian siswa dapat menyerap apa yang telah diajarkan oleh guru dan besar pengaruhnya terhadap pertumbuhan dan perkembangan potensinya.

Oleh sebab itu, guru harus memikirkan dan membuat perencanaan secara saksama dalam meningkatakan kesempatan belajar bagi siswanya dan memperbaiki kualitas mengajarnya. Hal ini menuntut perubahan-perubahan dalam pengorganisasian kelas, penggunaan metode mengajar, 
strategi belajar-mengajar, penggunaan media pembelajaran, maupun sikap dan karakteristik guru dalam mengelola proses pembelajaran. Dalam hal ini motivasi yang digunakan adalah dengan penggunaan metode yang bervariasi. Penggunaan metode yang bervariasi dapat meningkatkan semangat siswa. Penggunaan ini dapat menjembatani gaya-gaya belajar anak didik dalam menyerap bahan pelajaran. Motivasi belajar dari anak didik akan bangkit sejalan dengan penggunaan metode mengajar yang sesuai dengan kondisi psikologis anak didik.

Salah satu masalah yang sering dihadapi guru adalah bagaimana upaya dalam meningkatkan motivasi belajar dari dalam diri siswa. Sebab, keberhasilan suatu pengajaran dipengaruhi oleh adanya dorongan untuk belajar dalam diri siswa tersebut. Guru sebagai pendidik dan pengajar melakukan berbagai cara dalam rangka memotivasi belajar siswa. Antara lain memberikan pelajaran tambahan, memberikan pekerjaan rumah, remedial, sampai pada kerja kelompok.

SMP Negeri 2 Palangka Raya merupakan salah satu Sekolah Menengah Pertama Negeri yang ada di Provinsi Kalimantan Tengah tepatnya di Kota Palangka Raya, Saat ini siswa SMP Negeri 2 Palangka Raya telah mencapai 974 siswa. Selain itu, lokasi SMP Negeri 2 Palangka Raya bersebalahan dengan SDN 11 Langkai Palangka Raya.

Berdasarkan hasil obsevasi awal dan wawancara dengan guru IPS yang telah peneliti lakukan di SMP Negeri 2 Palangka Raya, dari 90 populasi siswa kelas VIII-8, VIII-9 dan VIII-10 masih ada siswa yang memperoleh nilai dibawah KKM (Kriteria Ketuntasan Minimal) yaitu 75 hal tersebut dikatakan oleh guru SMP Negeri 2 Palangka Raya, ini dikarenakan adanya siswa kurang aktif dalam mengikuti KBM (Kegiatan Belajar Mengajar) yang berlangsung. ada siswa yang menggunakan waktunya untuk hal-hal yang kurang bermanfaat dengan bermain dengan kawankawannya saat proses pembelajaran berlangsung, demikian halnya saat proses pembelajaran berlangsung hampir 50\% siswa seringkali sulit diatur asyik mengobrol sendiri dan tidak memperhatikan saat proses pembelajaran berlangsung.

\section{METODE PENELITIAN}

Penelitian ini menggunakan metode deskriptif, dengan jenis penelitian deskriptif. Pendekatan yang digunakan adalah pendekatan kuantitatif. Penelitian dilaksanakan di SMP Negeri 2 Palangka Raya yang berada di jalan Diponegoro No. 5 Kelurahan Langkai, Kecamatan Pahandut Kota Palangka Raya, Provinsi Kalimantan Tengah. Waktu penelitian akan dilaksanakan pada bulan April - Juli 2019. Populasi dalam penelitian ini adalah seluruh siswa kelas VIII-8, VIII-9 dan VIII10 di SMP Negeri 2 Palangka Raya Tahun Ajaran 2018/2019 sebanyak 90 siswa. Sampel pada penelitian ini ditetapkan sebesar 50\% dari jumlah populasi atau sebanyak 45 siswa. Adapun teknik pengambilan sampel dalam penelitian ini menggunakan simple random sampling. Teknik yang digunakan untuk mengumpulkan data dalam kegiatan penelitian ini adalah menggunakan teknik observasi, wawancara dan angket. Setelah data terkumpul dari hasil pengumpulan data, langkah selanjutnya adalah analisa data.

\section{HASIL DAN PEMBAHASAN}

Penulis telah mengadakan penyebaran angket keseluruh resonden yang telah ditetapkan yaitu sebanyak 45 orang, setelah penulis kumpulkan ternyata seluruh angket dapat terkumpul kembali dengan baik. Kemudian, perlu pula penulis jelaskan bahwa hasil observasi dan wawancara akan penulis sajikan sebagai data penguat dari hasil penyebaran angket. Setelah dilakukan penelitian dan pembahasan hasil data angket, selanjutnya peneliti menganalisis angket Upaya Guru. 
Adapun analisis angket Upaya Guru sebagai berikut.

Tabel 1. Angket Upaya Guru

\begin{tabular}{|c|c|c|c|c|}
\hline \multirow{2}{*}{ No Angket } & \multicolumn{4}{|c|}{ Tabulasi Data } \\
\hline & Selalu & Sering & $\begin{array}{l}\text { Kadang- } \\
\text { kadang }\end{array}$ & $\begin{array}{c}\text { Tidak } \\
\text { pernah }\end{array}$ \\
\hline 1 & 51,11 & 24,44 & 15,55 & 9,90 \\
\hline 2 & 35,56 & 28,89 & 22,22 & 13,33 \\
\hline 3 & 13,33 & 20 & 26,67 & 40 \\
\hline 4 & 68,89 & 20 & 11,11 & 0 \\
\hline 5 & 51,11 & 35,56 & 13,33 & 0 \\
\hline 6 & 71,11 & 20 & 8,89 & 0 \\
\hline 7 & 26,67 & 60 & 8,89 & 4,44 \\
\hline 8 & 15,56 & 22,22 & 44,44 & 17,78 \\
\hline 9 & 22,22 & 26,67 & 46,67 & 4,44 \\
\hline 10 & 42,22 & 51,11 & 6,67 & 0 \\
\hline 11 & 53,33 & 37,78 & 8,89 & 0 \\
\hline 12 & 48,89 & 28,89 & 22,22 & 0 \\
\hline Jumlah & 500 & 375,53 & 235,55 & 89,89 \\
\hline Rata-Rata & 41,66 & 31,29 & 19,62 & $\mathbf{7 , 4 9}$ \\
\hline
\end{tabular}

Berdasarkan tabel tabulasi di atas, terlihat responden yang menjawab selalu 41,66\%, sering $31,29 \%$, kadang-kadang 19,62\% dan tidak pernah 7,49\% responden yang ada. Dari hasil tabulasi angket Upaya Guru di atas, terlihat jelas sebagian besar siswa menyatakan guru IPS selalu berupaya memotivasi belajar siswanya di kelas maupun di luar kelas dengan cara memberikan angka/nilai, memberi hadiah, memberi ulangan, memberi pujian, memberi hukuman dan memberi metode pembelajaran yang bervariasi. Hal tersebut senada dengan pendapat (Sardiman A.M, 2010 : 91) ada beberapa upaya yang dapat dilakukan guru untuk memotivasi belajar siswa dalam kegiatan belajar di sekolah.

1. Memberi angka

2. Hadiah

3. Kompetisi/persaingan

4. Memberi ulangan 

5. Mengetahui hasil
6. Pujian
7. Hukuman
8. Hasrat untuk belajar
9. Minat
10. Tujuan yang diakui

Dari hasil angket, dan kaitannya dengan teori tentang Upaya Guru dapat disimpulkan bahwa guru IPS menunjukkan upaya guru yang cukup baik.

Setelah dilakukan penelitian dan pembahasan hasil data angket, kemudian menganalisis angket upaya guru, selanjutnya adalah menganalisis angket motivasi belajar siswa. Adapun analisis angket motivasi belajar sebagai berikut

Tabel 2. Angket Motivasi Belajar

\begin{tabular}{|c|c|c|c|c|}
\hline \multirow{2}{*}{ No Angket } & \multicolumn{4}{|c|}{ Tabulasi Data } \\
\hline & Selalu & Sering & $\begin{array}{l}\text { Kadang- } \\
\text { kadang }\end{array}$ & $\begin{array}{r}\text { Tidak } \\
\text { Pernah }\end{array}$ \\
\hline 1 & 53,33 & 37,78 & 8,89 & 0 \\
\hline 2 & 64,45 & 24,44 & 11,11 & 0 \\
\hline 3 & 60 & 24,44 & 15,56 & 0 \\
\hline 4 & 48,89 & 35,56 & 6,67 & 8,88 \\
\hline 5 & 22,22 & 26,67 & 20 & 31,11 \\
\hline 6 & 71,11 & 26,67 & 2,22 & 0 \\
\hline 7 & 26,67 & 22,22 & 13,33 & 37,78 \\
\hline Jumlah & 346,67 & 197,78 & 77,78 & $\mathbf{7 7 , 7 7}$ \\
\hline Rata-Rata & 49,52 & 28.25 & 11,11 & 11,11 \\
\hline
\end{tabular}

\section{Sumber : data diolah 2019}

Berdasarkan tabel tabulasi di atas, terlihat responden yang menjawab selalu 49,52\%, sering $28,25 \%$, kadang-kadang $11,11 \%$ dan tidak pernah $11,11 \%$ responden yang ada. Dari hasil tabulasi angket, dapat disimpulkan bahwa motivasi belajar siswa kelas VIII-8, VIII-9 dan VIII-10 sudah berjalan dengan baik. Ini dapat dilihat dari motivasi yang berasal dari dalam diri siswa yaitu dari keinginan siswa untuk belajar, sikap senang terhadap mata pelajaran IPS yang menunjukkan bahwa siswa memiliki minat yang cukup tinggi, dan selalu menyelesaikan tugas yang diberikan guru serta keinginan untuk meningkatkan pengetahuannya. Sedangkan motivasi dari luar diri siswa, dalam hal ini dapat terlihat pada semangat siswa ketika guru menyampaikan materi dengan menggunakan metode pembelajaran, kedisiplinan siswa dalam mengerjakan tugas yang diberikan guru dan sikap belajar siswa yang tekun dan sungguh-sungguh untuk mendapatkan pujian atau hadiah serta untuk menjadi juara. 


\section{Tabel 3. Angket Upaya Guru}

\begin{tabular}{|c|c|c|c|c|}
\hline \multirow{2}{*}{ No Angket } & \multicolumn{4}{|c|}{ Tabulasi Data } \\
\hline & Selalu & Sering & $\begin{array}{l}\text { Kadang- } \\
\text { kadang }\end{array}$ & $\begin{array}{r}\text { Tidak } \\
\text { pernah }\end{array}$ \\
\hline 1 & 51,11 & 24,44 & 15,55 & 9,90 \\
\hline 2 & 35,56 & 28,89 & 22,22 & 13,33 \\
\hline 3 & 13,33 & 20 & 26,67 & 40 \\
\hline 4 & 68,89 & 20 & 11,11 & 0 \\
\hline 5 & 51,11 & 35,56 & 13,33 & 0 \\
\hline 6 & 71,11 & 20 & 8,89 & 0 \\
\hline 7 & 26,67 & 60 & 8,89 & 4,44 \\
\hline 8 & 15,56 & 22,22 & 44,44 & 17,78 \\
\hline 9 & 22,22 & 26,67 & 46,67 & 4,44 \\
\hline 10 & 42,22 & 51,11 & 6,67 & 0 \\
\hline 11 & 53,33 & 37,78 & 8,89 & 0 \\
\hline 12 & 48,89 & 28,89 & 22,22 & 0 \\
\hline Jumlah & 500 & 375,53 & 235,55 & 89,89 \\
\hline Rata-Rata & 41,66 & 31,29 & 19,62 & 7,49 \\
\hline
\end{tabular}

Upaya guru IPS dalam memotivasi belajar siswa sudah berjalan dengan baik dapat terlihat dari keseluruhan data yang diperoleh yaitu guru IPS memberikan nilai, ada 23 siswa $(51,11 \%)$ mengatakan bahwa guru mereka selalu memberikan nilai dari setiap tugas yang mereka kerjakan. Memberikan hadiah, ada 16 siswa (35,56\%) mengatakan bahwa guru IPS selalu memberikan hadiah kepada siswa yang berprestasi. Memberikan ulangan, ada 31 siswa $(68,89 \%)$ mengatakan guru IPS selalu memberikan ulangan setiap sub pokok bahasan selesai. Memberitahu hasil, ada 32 siswa $(71,11 \%)$ mengatakan guru IPS selalu memberitahu hasil atau nilai ulangan kepada siswa. Memberikan pujian, ada 27 siswa (60\%) mengatakan guru sering memberikan pujian ketika ada siswa yang bersikap baik atau positif dalam belajar. Memberikan hukuman, ada 21 siswa $(44,44 \%)$ mengatakan guru kadang-kadang memberikan hukuman. Metode pembelajaran yang bervariasi, ada 24 siswa $(53,33 \%)$ mengatakan guru IPS selalu memberikan metode pembelajaran yang bervariasi disetiap pertemuannya. Memberikan nasihat, ada 22 siswa $(48,89 \%)$ mengatakan guru IPS selalu memberikan nasihat kepada siswa agar rajin belajar untuk mencapai cita-cita siswa. 
Penelitian ini membuktikan bahwa Upaya Guru sangat penting di dalam memberikan motivasi pada saat kegiatan belajar mengajar. Sehingga dampak dari pemberian motivasi tersebut yakni adanya rasa ketertarikan dan kesenangan siswa untuk mengikuti kegiatan pembelajaran IPS.

Tabel 4. Angket Motivasi Belajar

\begin{tabular}{ccccc}
\hline \multirow{2}{*}{ No Angket } & \multicolumn{4}{c}{ Tabulasi Data } \\
\cline { 2 - 5 } & Selalu & Sering & $\begin{array}{c}\text { Kadang- } \\
\text { kadang }\end{array}$ & $\begin{array}{c}\text { Tidak } \\
\text { Pernah }\end{array}$ \\
\hline 1 & 53,33 & 37,78 & 8,89 & 0 \\
2 & 64,45 & 24,44 & 11,11 & 0 \\
3 & 60 & 24,44 & 15,56 & 0 \\
4 & 48,89 & 35,56 & 6,67 & 8,88 \\
5 & 22,22 & 26,67 & 20 & 31,11 \\
6 & 71,11 & 26,67 & 2,22 & 0 \\
7 & 26,67 & 22,22 & 13,33 & 37,78 \\
Jumlah & $\mathbf{3 4 6 , 6 7}$ & $\mathbf{1 9 7 , 7 8}$ & $\mathbf{7 7 , 7 8}$ & $\mathbf{7 7 , 7 7}$ \\
Rata-Rata & $\mathbf{4 9 , 5 2}$ & $\mathbf{2 8 . 2 5}$ & $\mathbf{1 1 , 1 1}$ & $\mathbf{1 1 , 1 1}$ \\
\hline
\end{tabular}

Dari hasil tabulasi angket, dapat dilihat bahwa motivasi belajar siswa kelas VIII-8, VIII-9 dan VIII-10 sudah berjalan dengan baik. Ini dapat dilihat dari motivasi yang berasal dari dalam diri siswa yaitu dari keinginan siswa untuk belajar, sikap senang terhadap mata pelajaran IPS yang menunjukkan bahwa siswa memiliki minat yang cukup tinggi, dan selalu menyelesaikan tugas yang diberikan guru serta keinginan untuk meningkatkan pengetahuannya. Sedangkan motivasi dari luar diri siswa, dalam hal ini dapat terlihat pada semangat siswa ketika guru menyampaikan materi dengan menggunakan metode pembelajaran, kedisiplinan siswa dalam mengerjakan tugas yang diberikan guru dan sikap belajar siswa yang tekun dan sungguh-sungguh untuk mendapatkan pujian atau hadiah serta untuk menjadi juara. Dengan demikian, dapat disimpulkan bahwa motivasi memang penting diberikan di dalam kelas oleh guru. Hal tersebut dilakukan agar siswa memiliki motivasi yang kuat di dalam proses pembelajaran.

\section{Kesimpulan}

\section{KESIMPULAN DAN SARAN}

Berdasarkan hasil pembahasan di atas, maka dapat diambil kesimpulan sebagai berikut:

Setelah dilakukan penelitian dan analisis data, maka dapat disimpulkan bahwa upaya guru untuk memotivasi belajar siswa dalam pembelajaran IPS di SMP Negeri 2 Palangka Raya berjalan dengan baik. Hal ini terlihat dari hasil angket, observasi ataupun wawancara yang menunjukkan bahwa guru IPS berupaya cukup baik di dalam kegiatan belajar mengajar, sehingga siswa cukup 
termotivasi di dalam mengikuti kegiatan pembelajaran IPS. Berdasarkan sajian data dan pembahasan pada bab IV, maka kiranya dapat ditarik kesimpulan bahwa Upaya guru untuk memotivasi belajar siswa dalam pembelajaran IPS di SMP Negeri 2 Palangka Raya yaitu dengan cara memberikan anka atau nilai, memberikan hadiah, memberikan ulangan, memberikan pujian, memberikan hukuman dan memberikan metode pembelajaran yang bervariasi. Motivasi belajar siswa kelas VIII-8, VIII-9 dan VIII-10 sudah berjalan dengan baik. Ini dapat dilihat dari motivasi yang berasal dari dalam diri siswa yaitu dari keinginan siswa untuk belajar, sikap senang terhadap mata pelajaran IPS yang menunjukkan bahwa siswa memiliki minat yang cukup tinggi, dan selalu menyelesaikan tugas yang diberikan guru serta keinginan untuk meningkatkan pengetahuannya. Sedangkan motivasi dari luar diri siswa, dalam hal ini dapat terlihat pada semangat siswa ketika guru menyampaikan materi dengan menggunakan metode pembelajaran, kedisiplinan siswa dalam mengerjakan tugas yang diberikan guru dan sikap belajar siswa yang tekun dan sungguh-sungguh untuk mendapatkan pujian atau hadiah serta untuk menjadi juara kelas.

\section{Saran}

Berdasarkan pada kesimpulan tersebut diatas, maka saran yang perlu untuk disampaikan diantaranya seperti :

1. Kepala sekolah sebagai pimpinan lembaga pendidikan formal pada suatu unit kerja hendaknya senantiasa memperhatikan situasi dan kondisi unit kerja yang dalam hal ini guru-guru dan siswa-siswi yang terlibat didalamnya. Yang dalam permasalahan ini bagi guru untuk memotivasi belajar siswa sehingga siswa dapat meningkatkan kegiatan belajarnya.

2. Bagi guru-guru hendaknya lebih memahami dengan memberikan motivasi kepada siswa baik dari segi internal maupun eksternal, karena dengan demikian guru akan dapat memotivasi siswa dalam belajarnya.

3. Bagi siswa hendaknya mengutarakan secara jujur dan terbuka, baik kepada guru-guru maupun kepada orang tua tentang kesulitan belajar yang mereka alami, karena dengan demikian baik guru maupun orang tua akan membantu serta memberikan motivasi belajar pada siswa.

\section{DAFTAR PUSTAKA}

Achmadi, Abu. 2003. Didaktik Metodik. Semarang. Putra

Arikunto, Suharsimi. 2010. Prosedur Penelitian. Jakarta. Rineka Cipta.

Aunurrahman. 2010. Belajar dan Pembelajaran. Bandung. Alfabeta.

Darmadi, Hamid. 2011.Metode Penelitian Pendidikan. Bandung. Alfabeta.

Depdikbud. 1994. Kamus Besar Bahasa Indonesia. Jakarta. Balai Pustaka.

Depdikbud. 1996. Petunjuk Pelaksanaan Belajar Mengajar. Jakarta. Depdikbud.

Etika Wulandari. 2017. Kepemimpinan Kepala Sekolah Dalam Meningkatkan Motivasi GuruGuru Di SMP Byna Mulia Kecamatan Teweh Baru Kabupaten Barito Utara.

Gesang. 2013. Kinerja Guru IPS Pada SMPN 1 Manuhing Di Tumbang Talaken Kabupaten Gunung Mas.

Hamalik, Oemar. 2004. Proses Belajar Mengajar. Jakarta. Bumi Aksana.

Margono, S. 2009. Metode Penelitian Pendidikan. Jakarta. Rineka Cipta.

Mulyasa, E. 2003. Kurikulum Berbasis Kompetensi. Bandung. Remaja Rosdakarya.

Muhammad, Kasiram. 2008. Metodologi Penelitian: Refleksi Pengembangan Pemahaman dan Penguasaan Metodologi Penelitian. Malang. Malang Press.

Ngalim, Purwanto. 1990. Faktor-faktor Mempengaruhi Belajar. Jakarta Bina Aksara. 
Rusmita. 2013. Peranan Guru Dalam Meningkatkan Motivasi Belajar Siswa Kelas VIII SMPN-5 Kurun Kabupaten Gunung Mas.

Sanjaya, Wina. 2006. Strategi Pembelajaran Berorientasi Standar Proses Pendidikan. Jakarta: PT. Kencana.

Semiawan, Conny. 1985. Kemampuan Belajar Guru. Bandung. Bumi Aksara.

Slameto. 2003. Proses Belajar Mengajar. Bandung. Sinar Biru.

Sardiman, A.M. 2010. Interaksi dan Motivasi Belajar Mengajar. Jakarta. Grafindo.

Sudijono, Anas. 2008. Pengantar Evaluasi Pendidikan. Jakarta. Grafindo Persada.

Sugiyono. 2012. Metode Penelitian Kuantitatif, dan Kualitatif. Bandung : CV ALVABETA

Sudjana. 2001. Metode tatistika. Bandung:Tarsito

Surakhmad, Winarno. 1985. Pengantar Penelitian Ilmiah Dasar Metode Teknik. Bandung. Usman. 1995. Pengantar Ilmu Pendidikan. Jakarta. Bina Aksara.

Winkel W.S. 1999. Psikologi Pengajaran. Jakarta: Grasindo. 